Etnográfica

Revista do Centro em Rede de Investigação em

Antropologia

vol. 15 (1) | 2011

Vol. 15 (1)

\title{
The ambivalent relation between state and illegal actors: piracy retail in Mexico
}

A relação ambígua entre o Estado e os atores ilegais: o mercado da pirataria no México

José Carlos G. Aguiar

\section{(2) OpenEdition}

Journals

Electronic version

URL: https://journals.openedition.org/etnografica/840

DOI: $10.4000 /$ etnografica.840

ISSN: 2182-2891

\section{Publisher}

Centro em Rede de Investigação em Antropologia

\section{Printed version}

Date of publication: 1 February 2011

Number of pages: 109-128

ISSN: 0873-6561

Electronic reference

José Carlos G. Aguiar, "The ambivalent relation between state and illegal actors: piracy retail in Mexico", Etnográfica [Online], vol. 15 (1) | 2011, Online since 23 October 2011, connection on 11 February 2022. URL: http://journals.openedition.org/etnografica/840 ; DOI: https://doi.org/10.4000/ etnografica.840

\section{(c) (1) (9)}

Etnográfica is licensed under a Creative Commons Attribution-NonCommercial 4.0 International License. 


\title{
The ambivalent relation between state and illegal actors: piracy retail in Mexico
}

\author{
José Carlos G. Aguiar
}

In the rise of democratic governments across Latin America, the neoliberal law-and-order perspective has been the most influential model of security in the region. This approach is based on the opposition between state and illegal agents, as if they were two different sets of actors. Influenced by this model, Mexican president Vicente Fox launched an extensive anti-piracy programme to eradicate retail of counterfeit. Based on ethnographic material gathered in the San Juan de Dios market in Guadalajara, I discuss on the exchanges between piracy sellers and police officers. My argument is that law enforcement programmes have not affected the political economy of corruption, they overlook the net of ambiguous loyalties where state and illegal actors are entrenched. The anthropology of the state provides the rationale for a critique on neoliberal security policies.

KEYWORDS: piracy, illegality, police, Mexico.

THE RELATION BETWEEN STATE AND PRIVATE ACTORS IN THE organisation of illegal activities has been documented in the ethnography of smuggling, drug trafficking, corruption and the political economy of gifts in Africa, Asia, Latin America and, to a much lesser extent, in Eastern and Western Europe. In the anthropology of the state and illegality there are two analytical standpoints that come to the fore. First of all, the involvement of state actors in unlawful activities is explained as a shortcoming of the state, that is, state malfunction causes corruption. In sub-Saharan Africa, the works by Nugent and Asiwaju (1996), Chabal and Daloz (1999), and Bayart, Ellis and Hibou (1999) present evidence on the multiple accommodations between smugglers and officers, giving room to an exchange of favours and values. State corruption is not an exception, but "a habitual part of everyday life, an expected 
element of every social transaction" (Chabal and Daloz 1999: 99). States in West Africa that result from the experience of European (de)colonisation are intrinsically ambivalent, since they represent and endorse the rule of law, but also participate and benefit from the activities they should proscribe.

"[T]he state is simultaneously illusory and substantial. It is illusory because its modus operandi is essentially informal, the rule of law is feebly enforced and the ability to implement public policy remains most limited. It is substantial because its control is the ultimate prize for all political elites [...] The state is thus both strong and powerless, overdeveloped in size and underdeveloped in functional terms" (Chabal and Daloz 1999: 9).

In this context, the state integrates both the formal and illegal domains. Hibou (1999) argues that these national states are not weak, since they are materialised and present in regulations and paperwork; they are neither shadow, because there is no workable distinction between the state apparatus and illegality. State officials ease up, for instance, the work of smugglers with "dirty tricks", the falsification of documents to avoid customs duties (Hibou 1999: 102-1 13). Hence, Hibou choses the term "alter ego" to catch the ambiguous way the state simultaneously enforces the law and organises illegal activities in Zimbabwe, Uganda and Nigeria:

"[T]he state participates actively in the informal economy, especially in matters affecting international trade [...] It is a characteristic of every sphere in which the state intervenes in Africa, as much in economic relations of exchange and production as in political and social relations" (Hibou 1999: 89).

In a similar analysis, Van Schendel (2005) illustrates in his work on the Bengal borderland the limits of the state in the definition and control of commodity flows at the national borders. State officers in South Asia are key actors in the regulation of smuggling. The cases in Asia and Africa represent early stages within the larger cycle of state formation: countries with disputed or unclear frontiers, vulnerable officers in need of professionalisation. A consolidated nation-state would effectively enforce the rule of law and surveil its national borders (Cunningham and Heyman 2004). Up to this point, there is a normative perspective in the analysis of the relation between state and illegality.

"It is therefore assumed that a more pervasive public exercise of social discipline through state institutions will work to prevent corruption by stifling the selfish greed of individuals" (Hasty 2005: 271). 
From a second analytical standpoint, arrangements between state and illegal actors render stable systems of corruption. The literature points at the "solid" nature of the political economy of corruption. State and illegal actors are integrated through systematic corruption, bribery, and exchange of gifts. The relation between state and illegal actors renders parallel forms of taxing and state expansion (Cross 1998; Lomnitz-Adler 2000).

In the $21^{\text {st }}$ century, with neoliberalism as the dominant ideology, there is a renewed attention upon the normative perspective on corruption. Projects are introduced to "modernise" national states and bring them to the "law-andorder" principles promulgated by corporate power. State reform or adjustment are euphemisms of state domestication. Neoliberal policies are "transferred" from one region of the world to the other, homogenising security programmes in countries and cities (Rose 1991; Evans and Davies 1999). Anti-corruption and security programmes are relevant examples of this, which have been promoted across Latin America.

Through the $20^{\text {th }}$ century, the permanence in power of political elites or parties was the main objective of the security agenda for Latin American governments. This is the national security model, that was focused on the control of dissidence and opposition to (semi)dictatorial regimes. In the context of democratisation, there is in the region since the 1980s a transition from the national security to a citizen security scheme (Dammert 2007). Security policies aim at guaranteeing the security of the citizenry. They are influenced by a law-and-order perspective, with the US government as promoter in the international playground (Bailey and Dammert 2006; Tulchin and Ruthenburg 2006). This model is based on legal enforcement through reactive plans of action that target illegal and criminal economies or actors; it privileges the use of public force over more comprehensive or proactive policies. Even more, this model is anchored on the opposition between state and illegality, assuming that illegal actors essentially are anti-state actors (Aguiar and Suárez de Garay 2008).

Under the influence of the law-and-order model, a number of national governments in Latin America make use of a belligerent discourse to launch "wars" against social problems. Brazil, Colombia, El Salvador, and Mexico have declared wars on informal commerce, urban delinquency, drugs, smuggling or terrorism (Cross 1998; Cano and Santos 2001; Diamint 2004). Far-embracing programmes, often financed by the US government, promote zero tolerance, revanchism, populist punitiveness and the criminalisation of poverty. These programmes shape national and local security agendas, leading to some kind of "franchising" of security policies across the region.

Based on this perspective, the Mexican president Vicente Fox (2000-2006) embarked in the "war on piracy". This programme placed the reduction of piracy retail as a priority in the security agenda and directed police action against marketplaces and street vending across the country, reaching more than 
six thousand seizures in 2006 (Aguiar 2010). Never before so much attention and resources were devoted to the protection of intellectual property rights.

In this article I present ethnographic material collected between 2003 and 2010 in the San Juan de Dios market in the city of Guadalajara, Mexico, to discuss on state and illegal actors, and the uncertainty and risk constitutive to their relations. ${ }^{1}$ Given its pivotal function in the production and trade of bootleg, this marketplace has become a main target in the anti-piracy programme launched by president Fox.

\section{STATE AND ILLEGALITY: A POROUS FRONTIER}

Corruption worked in Mexico as an agglutinating factor in the formation of the one-party system that governed for the most part of the $20^{\text {th }}$ century. The political culture nurtured by the Partido de la Revolución Institucional (PRI) is ambiguously defined by cultural nationalism and corruption. By making reference to surveys on Mexican public opinion carried out during the 1950s, Morris points to the fact that the "extraordinarily low levels of trust in relation to the political system, the police and politicians" (Morris 2000: 223-224) are a typical feature in the historical evolution and integration of the PRI state in Mexico. This may seem a contradiction, since belief in legality is one of the most common sources of legitimacy. According to Weber, belief in and respect for the law are a powerful resource for the construction and maintenance of political orders (Weber 1978). The validity of a legitimate order lies at the core of a state's functioning; it is its ultimate source of power and justification. However, if the authority systematically fails to protect the legal order, or if the authority tolerates and promotes the suspension of law, then the authority will lose its justification and legitimacy (Heidenheimer 1970). Yet, corruption has been a resource that political groups have utilised in order to form and impose political regimes, as observed in early state development in Europe (Blok 2001).

In the context of modern societies governed by national states, in the scholarly literature it is widely assumed that corruption undermines the very source of political authority, necessary for the establishment and maintenance of a political order. Corruption, the "use of a public faculty for obtaining particular benefits, generally by transgressing the rule of law" (Lomnitz-Adler 2000: 12) can erode the validity of the political system. Following Heidenheimer and Johnston (2005), corruption can work in three spheres: as offence by a public servant (juridical domain), as an economic measure taken by a public servant (market domain), and in the subversion of the public interest because of a personal interest (political domain). These three domains are not mutually exclusive, given that, for instance, a personal benefit (political domain) might 
take place as a result of the suspension of the rule of law (juridical domain). Corruption has thus an instrumental character: the suspension of the rule of law in the pursuit of an interest.

"Illegal practices are not the monopoly of criminal elements, but rather various kinds of illegality, such as black markets, bribery and undocumented capital flows, are options taken up by identifiable classes, regional groups, ethnic groups, etc. at distinctive times. [G]roups involved in crimes are not isolates but act always in the field of relations - class relations, relations to the state, relations to natural resources, etc." (Heyman 1999: 13).

Although corruption was an integrating factor of the PRI regime, there is little research in Mexico based on ethnographic material for the study of corruption. This is perhaps in part due to the difficulties inherent to this kind of fieldwork. The mechanisms and agencies that emerge between state and illegal actors are highly elusive.

In Los Policías: Una Averiguación Antropológica, Suárez de Garay describes the processes of identification inside the municipal police of Guadalajara, and the relations police officers establish with "the other", that is, the social actors with whom officers come in contact on the street (Suárez de Garay 2006). The core argument Suárez de Garay poses is that the police are in fact ruled by otro orden (another set of values), a world different from the one the institution should enforce.

"The networks and habits of corruption are amongst the main problems of the police institution. Any officer who becomes part of it knows about the metamorphosis everybody undergoes when becoming part of the real world of the police, so far away from the values that the academy tries to convey" (Suárez de Garay 2006: 269; my translation).

Policing practices and the relation between police and society are mediated by corruption and mistrust, and they do not correspond to the institutions' officially-stated purpose. Fraud and bribery become daily practices, and give shape to the perceptions and expectations of police officers; corruption becomes part of the social fabric, developing a particular police culture, a Weltanschauung at the heart of the institution. The relation between the police and illegal actors is ambiguous, often contradictory. The police frequently become part of the problem they are fighting against (Martínez de Murguía 1999), since criminal networks can also integrate officers, who benefit from selling their complicity with illegal actors. These perspectives point out to the porous frontier between state and illegal actors, and the difficulties in distinguishing the state from the actors it should prosecute. 
Corruption seems to show an apparent contradiction: the state attempts to reduce the illegality it actually promotes. In the scholarly literature, it is assumed that corruption deters the system of law (Bayart 1999; Haller and Shore 2005). Yet, by participating in both the formal and illegal domains, the state gains control over these two overlapping orders and benefits from them. Up to here, corruption works as a resource for power constitution, through which the state wins access to and orders the illegal world.

\section{PIRATERÍA: THE POLITICAL ECONOMY OF CORRUPTION}

The city of Guadalajara was founded in 1542 by Spanish colonisers and is the second largest city of Mexico, with more than 4 million inhabitants in the metropolitan area (INEG 2005). Trade, services and electronics industry are the main economic activities. Although the city doubled its population in ten years (1995-2005), it has preserved its "traditional" identity, with a characteristic historical centre. Next to the Plaza Tapatia, the centre's main square, stands the San Juan de Dios market, founded in the $16^{\text {th }}$ century.

The marketplace still is a pivotal trading point in the city. About three thousand sellers work in the 1600 stands the market has, and although there are no official records on the amount of visitors, the administration of the market estimates up to thirty thousand people a day in a busy weekend. The colourful and festive environment in the market that locals name "tradition" and "identity" is ambivalent, since this commercial space houses a number of illegal activities (prostitution, drug trafficking, contraband retail). More importantly, the market has become a target of the anti-piracy programme set up by the federal government. Once every month or two, the federal police raid the market to confiscate bootlegged merchandise.

In a Thursday morning, it seems a seizure has just taken place. There is something unusual. Many stalls are still closed. There is a sort of stress in the air. Retailers walk fast, almost running, carrying sizeable cardboard boxes and black garbage bags from one place to another. Oddly enough, there are piles of boxes standing in the corridors, as if they have been left behind or somebody is going to pick them up. The usual noise and hubbub is substituted by a laconic, heavy atmosphere: the red metal shutters of the stalls shut down and secured with heavy locks. There are barely any shoppers. The only noise is the steps of the retailers transporting merchandise. They move silently, lightly but quickly, as if they do not want to be noticed. There is not only stress, but also fear. A sellers says: "They [the police] were already here in the early morning".

Piracy retailers are expecting the federal police to come back at any moment, and they are getting ready. There is little time to hide the merchandise. Just as in a fire drill, retailers act so quickly and resolutely that it becomes clear they have done this many times before. Yet, once again: to pack, as fast as possible, 
discs in boxes (the new releases, the good copies, the most sold ones); close and tape the boxes, and then hide them in the stall of a relative or a friend who does not sell bootleg, or in the warehouse of the patrón where the merchandise can be kept safe. The federal, as they call the federal police, would normally only come to raid the stalls on their list, where there is official proof piracy is sold. Hiding pirate DVDs in a vegetable stall is therefore safe. Once the merchandise is hidden and the stall closed, there is not much else to do. Then it is, for the retailers, time to wait until the raid is over.

Two young men in their mid-twenties carry big black garbage bags through the long and narrow corridors of the market. All of a sudden, they stop and unlock one stall, fold the metal shutter up and deposit their bags inside. There are CDs and DVDs in the bags they are hiding. They have heard about the police to come.

"Yes, and they are all dressed up [the police officers, as civilians], and that is why they have not opened yet [the most of piracy sellers in the market]. We have to store them here [the discs], because they come to check the stall, maybe not right now, but anyhow, everybody is stowing the merchandise".

A bit further along, a few piracy stalls are open: the DVDs are on full display and the retailers are not packing, or putting discs in bags. Quite to the contrary, they seem very relaxed and chatty. Why do they behave so laid back if the police are about to come? "Them, always. They have more palancas" (literally, handles: to have contacts), tells Doña Luz, a seller of counterfeit jeans and shirts. Having the right contacts ensures access to reliable information and arrangements.

DOÑA LUZ - The raid was to be last night. And they [retailers] took everything away. They were warned before, so, I do not know if they already have the green light [authorisation] to work again.

AGUIAR - So the raid was [emphasis] last night?

DOÑA LUZ - I have not heard anybody, anything. Maybe it was a false alarm; maybe later today... They are like, "we open, we do not", "we do, we do not" and so. The most fearless have already opened again [...] since last night, they were taking everything out. How awful, just to see those ugly men, armed, it feels so awful. They do impress, and scare you; just imagine they tell you: "Hey, take everything out and come with me to tell..."

That day the police did not come to seize the marketplace. The raid did not take place during the night before nor the day after either. In the end, it was, as Doña Luz put it, a false alarm. 


\section{Mordida}

To give a bite (dar una mordida) or get bitten (ser mordido) are typical expressions of the political culture in contemporary Mexico. They are political since they illustrate a distinctive sort of interaction between citizens and their authorities.

The payment of a mordida can be indicative of the normalisation of corruption: a mordida is an occasional, circumstantial bribe, and it can be paid either voluntarily (bribing as a resource for avoiding the rule of law) or forcibly demanded (an officer, from his empowered position, asking for a bribe). Civilians in Mexico are confronted by situations in which they feel that bribery is the only possible way out. Car drivers who cross red lights, and prefer to avoid the procedure involved in paying a fine, offer a mordida to the police agent who stopped them. As do businessmen and citizens to ease up paperwork. In the context of the PRI state, the mordida became regular, normalised corruption to handle governmental procedures, or a way to bypass the rule of law.

"[In the state created by the PRI regime] bureaucracy not only penetrates practically every activity of social life (where almost everything requires some paperwork or bureaucratic procedure), yet the citizen has limitated institutional means to prevent the bureaucrat from abusing of his authority. Overall, the structure of the particular situation exposes the citizen to the conceited wishes of the bureaucrat, which in the end makes quite rational that the citizen accedes to pay the "mordida'" (Morris 2000: 226-227).

Corruption practices are widely accepted in the San Juan de Dios market. Since popular markets and street vending are a socioeconomic space that has been historically framed in the realm of informality, mordidas are the very resource used by vendors to win some power and avoid municipal regulations. Bribing authorities has made possible the rise of commercial activities in places or zones in the cities where vending is not allowed (i.e. downtown pedestrian streets), or to tolerate the retail of merchandise that is not legal (Cross 1998; De la Peña 2000). Piracy retail in the San Juan de Dios market occurs within this framework: norms and regulations are neutralised by bribery.

Market retailers are accustomed to the mordida. PRI-related leaders used their authority to collect financial resources through the payment of mordidas. In order to be granted a license to retail, a stall or a permit, the vendor was expected to pay, on top of the costs of the paperwork, a mordida that ended up as a gratification in the pockets of municipal officers. Many market tenants find that this structure offered an "easy" or more "comfortable" way of solving practical affairs, since they paid the mordida and forgot about the matter. On the other hand, the retailers of illegal merchandise assume that mordidas were simply the price they had to pay for the illegal nature of their activity. 
While the Partido de Acción Nacional (PAN) government in Guadalajara² had overtly and repeatedly manifested its compromise with transparency and honesty, in the San Juan de Dios market this desire for a less corrupt administration is countered by the persistence of the mordida. Even today, mordidas continue to be a useful and no less successful mechanism, which piracy retailers resource on. Given that the PRI-related leaders have more or less been put out of commission, bribes now follow a different circuit. Indeed, bribes are still paid to two kinds of actors: municipal officers and police agents. Municipal supervisors often argue it is either not their remit or primary task to prevent the sale of pirated material. This is despite that fact that the municipal regulations for markets and tiangüis (street markets) clearly stipulate that all merchandise should be of a legal nature. Yet, occasionally supervisors will control market vendors or peddlers around the market; the retailer knows that it is not the supervisor's aim to seize the merchandise or close down the stall, but instead to receive a mordida, which he can demand because the retailer is not observing the law.

In and around the San Juan de Dios market, bribes are often paid to municipal supervisors during the Christmas Season. Since peddling is not allowed in municipal markets, peddlers pay between 100 and 200 Mexican pesos (USD 9 to 18) a day to supervisors to let them to continue retailing, or they may even come to a "seasonal agreement" paying up to 12,000 pesos (USD 1090) for the four weeks prior to Christmas Eve.

The municipal government acknowledges that the mordida is still a common practice, that bootleg retailers bribe officers and that supervisors are often involved. In interviews with the Secretary of Government of the City of Guadalajara, and the Director of Markets of the City of Guadalajara, both top officials explained this as the result of long-lasting practices of the political system inherited from past administrations - i.e. the PRI regime in which corruption had become normalised. In this way, retailers "automatically" react by paying a bribe, since they were used to doing so. With this line of thinking, the PAN authorities minimise corruption as an inheritance from the past, a cultural fact.

Given that copyrights are protected under the Federal Penal Code, the federal police is the institution that seizes pirated merchandise. Nonetheless, a mordida may still prevent the police from confiscating illegal goods. However, it is not always certain that police officers will accept a mordida. Since the mordida corresponds to a circumstantial bribe, where the two parties negotiate and agree on the amount to pay, it is not sure whether the police will accept the bribe, or that the seller will stay calm enough to negotiate the mordida successfully, since a chance exists that in the end the merchandise will be confiscated. 
There is no fixed amount of money for a mordida; the seller and the police set it after negotiation (actual bargaining) and in relation to the severity of the infraction. When an important amount of merchandise is at stake, the bribe can thus be higher.

Vendors in the San Juan de Dios market, however, argue that raids aim at "showing off" a powerful hand of the police against piracy. After meeting the mordida, sellers who were previously detained are back in the market, with their stalls open and retailing exactly the same merchandise. It is also known that piracy vendors go to the police warehouses and bribe officers in order to retrieve their confiscated merchandise, as Héctor Contreras, a local journalist, explains:

"When [the police] carry out seizures, it is just pure show. The vendors later go to buy their merchandise directly from the police offices, 'Hey, we want our merchandise back'. They pay a certain amount of money and it is handed back".

\section{Madrina}

In the networks of retail and supply territorialised in the San Juan de Dios market, the madrina (godmother) has a critical function. In order to minimise the risk of a police raid, which may result in the confiscation of material or detention, vendors make use of the various services their supplier offers. A CD supplier becomes an "entrepreneur" when he broads the array of services to retailers. He provides not just merchandise to the sellers, but also informal credits, bookkeeping and security. The entrepreneur is a smuggler of CDs inserted into international networks, who owns copying facilities (laboratorios) where CDs and DVDs are reproduced, and wholesales the material among vendors in the marketplace.

Merchandise is often given to sellers on consignment, a service that deepens the relationship between entrepreneurs and vendors. Entrepreneurs also have contacts in the police, through contact with a madrina. The madrina is a broker who mediates between the police and the sellers, he trades security and police information and communicates between the world of the police and the world of illegal actors.

"[P]olice forces had scores of secret agents who were known as 'madrinas', or godmothers, who were kept off the books but whose responsibilities went far beyond those of informers. They were often allowed to carry guns and were used by federal and state police chiefs to do the dirty works that couldn't be done by those on the government's payroll - from stealing cars across the border to killing opposition activists. [T] he fact that the madrinas were not kept on a regular payroll gave them a virtual license to 
commit crimes and fostered additional corruption within the regular forces" (Oppenheimer 1996: 303).

The brokerage and intermediation functions of the madrina are comparable to those of the cacique (strongman) studied in the scholarly debate around state formation in $20^{\text {th }}$ century Mexico (Bartra and Huerta 1975; De la Peña and Escobar Latapí 1986; Knight 1986; Pansters 1997; Knight and Pansters 2005). The role of caciques and madrinas demonstrates that in the corporatist context of the one-party system, the PRI, as a national party, integrated and developed parallel structures that ultimately nurtured a regime of exception. As a result, relations between the sate and citizens are mediated by informal actors.

The madrinas in the San Juan de Dios market have a number of contacts with the police, and connect informal and formal networks. In some cases, the madrina is a former police officer who was sacked and no longer works for the institution. ${ }^{3}$ He can sell his services as a provider of police information to illegal actors or perform dirty work.

"To minimize the impact of distorting elements in the corruption system, the police make use of informal networks to exercise more control on the recruitment of new agents and 'madrinas' [...] Here, kinship or compadrazgo (godfathership), along the solidarity networks created amongst corrupt policemen, are helpful" (Resa 2001: 25-26).

In the San Juan de Dios market Eduardo Saldaña is a well known madrina among sellers of bootlegged CDs and DVDs. People in the market might say that Eduardo studied accounting in the public University of Guadalajara, but in more intimate conversation, they will admit he is a former police officer. To the world, Eduardo takes care of retailers' paperwork; to the retailers, he provides security and information on upcoming police seizures. Eduardo skilfully displays his professional side as an accountant, and would never use the term madrina to describe himself. Eduardo owns a company offering financial advice, Asesoría El Mañana, and has an office in the lower middle-class north side of the city. His clients are sellers of pirated CDs, contraband and counterfeit, who pay him an honorarium for his services. By providing this accounting service, Eduardo has access to information on the earnings of sellers at the market, his clients.

Eduardo is able to perform in different social and political settings and is used to handling the local media. He has been quoted by local newspapers

3 Betrayed or caught in serious cases of corruption, fired policemen become madrinas once their career within the institution has come to an end. As madrinas officers sell information they still have access to through their former colleagues. 
when the federal police raided the San Juan de Dios market, lobbying for the retailers' interests. He has also appeared a couple of times on TV, encouraging the reconversion (conversion) of piracy sellers, in meetings and debates with the different parties of the music industry.

As a madrina, Eduardo regularly attends the market tenants' meetings, where the sellers and their representantes (agents) gather and discuss problems. In one of these sessions, Eduardo showed once again his sartorial flair. He wore gold rings, bracelets adorned his hands and wrists, his shirt was half unbuttoned showing his hairy chest, a showy mobile hung from his belt, and despite being young (he is not even 40 years old) looked somehow older and wasted. He introduced himself as the representante of the piratas and fayuqueros (the representative of vendors of bootlegged goods and contraband). During the PRI government, these representantes would be labelled as leaders, yet in the current political transition, representante is a neutral term. During the meeting, Eduardo was to introduce his proposal to the tenants to organise a fair in the main patio of the market, where different local producers would be given the chance to offer their products directly to the tenants. Eduardo pointed out the great opportunity to be able to profit from direct supply, low wholesale prices, and the bigger choice of merchandise to sell. He spoke slowly and carefully, describing the demands of the new era of globalisation, where there are new challenges to be faced. He argued that retailers should not "stay in the past", selling small amounts of handmade sandals and folkloric handicrafts. Ramona, who sells leather sandals, was visibly uncomfortable at being depicted as part of the past and regarded Eduardo suspiciously.

Eduardo thus has two roles. One he displays as the representante who engages in public debates and enjoys media exposure, based on the professional assistance he offers. In the other, more obscure role, Eduardo is a madrina, the central link in the network, providing information and security to piracy retailers in the San Juan de Dios market, and saves his protégées from police action.

\section{Cuota}

In a similar fashion to illegal or mafia-based organisations (Blok 1975; Heyman 1999; Paoli 2003; Koonings and Kruijt 2004), monthly payments are collected from piracy retailers in order to bribe the federal police. Vendors organised by Eduardo pay a cuota (quota), a payment between USD 40-70 per seller, depending on the merchandise and the size of the stall. The cuota flows upwards through the contacts the madrina has, and finally reaches higher levels of the police structure, like a federal police commander, with whom a madrina deals. Madrinas and police commanders negotiate via subcommanders, because, as Sergio, a bootlegged DVD seller and former madrina explains, "the head will never show his face". Once the commander takes his share, the bribe atomises and flows down to police officers, as Néstor, a vendor of pirate DVDs explains: 
"Somebody collects the money, and takes it to the federal police, so the police turn a blind eye, and they even say 'that day we are coming, so you get ready'. We take away the good discs and leave just waste, bad discs, just to, to do as if... so they can say, 'something's come up', but everything is full of corruption".

Although a mordida and a cuota are both in the end bribes, they are different. A mordida is a circumstantial bribe, paid after the negotiation between the two involved parties; it is never assumed that the outcome of this negotiation will be positive for the retailer, since there is the chance that the officer will not accept the bribe. Since it is a circumstantial bribe, the mordida covers one action, one time. The cuota, on the other hand, is a more structural bribe, a set arrangement that flows upwards in the hierarchy of the organisations involved. It ensures safety and provides evidence of the degree to which illegality is embedded in the corporatist state. Andrés, a vendor of pirated DVDs, points out:

"[E]verybody who works here pays a cuota. [Then he lowers his voice and whispers] Yet it does not mean anything you say, 'that is not risky'. It is not a security. You have to pay to... it is assumed they warn you, but they cannot guarantee that they [the police] will not attack you".

A tool with a double edge, the cuota is a resource that neutralises police action, but it is at the same time a means of coercion too. Retailers are put under pressure to meet the monthly fee. They know that the cuota provides a certain degree of security, and that by not taking part they become an easy target for the police. Police action can be routed to affect retailers who do not contribute or represent a threat to a given madrina.

\section{Pitazo}

While cuota money flows upwards in the piracy structure, reaching entrepreneurs and madrinas, the pitazo runs the other way around, top-down. The pitazo is the information the cuota-paying seller receives from the madrina on upcoming police action. Once alerted, sellers can protect their merchandise. They may leave some merchandise behind in their stalls (old CDs, for instance) just to fake the seizure.

At first glance, the cuota and pitazo systems suggest a well-oiled network in which federal police, entrepreneurs, madrinas and sellers smoothly cooperate. But, in addition to the potential hazards of unaccountable police, sometimes the lines of communication are blocked. Hence, pitazos are not always reliable. But if a pitazo is passed on, retailers must hide their merchandise. They cannot afford a mistake; the money invested in the merchandise has to be 
protected. Futher, pitazos may stop circulating when a new police commander is appointed in the zone. Informal deals must be renegotiated, and while the new commander usually agrees to continue them, higher cuotas may be demanded. Then, pitazos will not perform until the commander and the madrina come to a new arrangement, and this process can take months. In this uncertain interim period, unexpected raids may occur.

Contacts between police officers and piracy entrepreneurs are to a certain extent structured, since they do not rely on the favour of one (sub)commandant in particular, but rely instead on agreements that are typically honoured. These negotiations are no secret to local authorities. In interviews with highranking government officers, such as the Supervisor of Municipal Markets, the Director of Markets of Guadalajara, the Secretary of Government of Guadalajara, the Secretary of Public Security, or the Administrator of the San Juan de Dios Market, the authorities acknowledged the efficiency of madrinas and pitazos. The Secretary of Public Security for Guadalajara even describes the situation as a sort of natural development:

"We have to speak the truth, haven't we? One of the biggest problems is corruption, right? And I have a theory, maybe it sounds a bit odd. I call it the fly theory. A fly, when it is tired of crashing against a glass, looks for another way out. And many times the policeman is like that: he sees so much of, in this case, the retail of pirate things, and sees that he cannot do anything, then he tries to take advantage. He says, 'OK, I know that what you do is not legal; that what you do is bad. Then, I do not punish you; I do not pick the discs you are selling that are illegal. Give something to me'. And there is in many cases corruption in this regard, and it happens; we have to acknowledge that it occurs many times".

In this statement, the police, as an institution, perceive themselves as powerless in the face of piracy. It is revealing how the Secretary described the role of the police: after all the attempts to enforce the law, a policeman "cannot do anything" but try to profit from it, "to take advantage". According to Pablo Lasso, a local scholar who specialises in informal commerce in Guadalajara, this attitude of knowing but not taking action includes a double standard:

"The government plays with two different sets of cards. One of dignity and honesty; at the upper levels, [corruption] tears them apart. And then, those at the lower levels who are appointed to uproot corruption, sadly, those are bought off $[\ldots]$ but when they are forced from above, we know that now and then somebody will be picked and the merchandise seized, but they do it randomly and try to not always raid the same retailers". 
Many note that political discourses on transparency and the fight against corruption are little more than lofty rhetoric, since it does not lead to reform of the enforcement institutions. Mario, a market seller, put it succinctly: "The famous honesty is a bluff".

"Everybody profits from it because there is a scandalous corruption. Nobody knows anything, but everything is under control. And if they [the police] come in the morning, by noon they [retailers] have discs to sell again."

\section{DEBATE: DOES CORRUPTION EXPAND STATE POWER?}

The ambivalence of the federal police in anti-piracy programs helps to study the rise of bootleg in Mexico. The piracy index (percentage of pirated material of the total available) was estimated at 63\% in 2000 and increased to $80 \%$ in 2008. For the same period, retail of legal CDs plummeted $60 \%$ which resulted in the massive closing of established shops for recorded music (Aguiar 2010). In the San Juan de Dios market the amount of bootleg sellers has not visibly decreased, it is likely the opposite. Anti-piracy measures show little success, if any. Therefore, a closer analysis is here necessary to assess the impact of corruption in policing practices, and the benefits from the ambiguous interaction between state and illegal actors.

From a normative point of view, corruption erodes the rule of law and undermines the authority of state actors (Tulchin and Ruthenburg 2006). Yet, from an integrative perspective, corruption generates supplementary mechanisms for state expansion, which include parallel taxing or political dominance. The last is the case of gunmen and death squads in Brazil and Guatemala that extend the presence and power of the state through illegal, violent actors (Van Reenen 2004). In her study of banditry, unregulated commerce and corruption in the Chad Basin, Roitman describes the exchange of financial resources between officers and smugglers to conclude the following:

"[corruption is constitutive of the] 'normal order,' as licit activities insofar as they are admissible and have in some ways come to represent certain truths about the economic, or about ways of acting effectively in the economic realm $[\ldots]$ maintaining states of illegality is a mode for establishing and authenticating the exercise of power over economic relations and forms of wealth" (Roitman 2006: 264).

Clearly, the state here is not a super-structure above social relations and regulating all exchanges with basis on a regime of legitimacy. State actors are, thus, not the bureaucrats Weber identified: the embodiment of the professional 
competences and principles defined by the state. In fact, the political authority and the regime of legitimacy are fuzzy constructs. Corruption and illegality, as Gupta points out, are contested:

"When considering modern bureaucracies, thus, even when an unambiguous legal mechanism exists to determine corruption, if there is no widespread social agreement about which scale is to be used to judge 'correct' ethical behavior, the social judgment of corruption can often be contentious and fractured" (Gupta 2005: 8).

Implicitly, normative and integrative approaches suppose that the arrangements between state and illegal actors are reliable. Corruption generates some kind of trust: the exchange of values provides illegal actors with certainty. The outcome of this process can be either the constitution or erosion of state power. In both the disintegration and the expansion of the state underlies the assumption that these arrangements do establish fixed protocols on base of which these two sets of actors negotiate, coexist or cooperate.

Piracy sellers meet cuotas and take risks because they perceive their undertaking (retail of an illegal product) as a social right, that is, a licit illegality; interestingly, they do not necessarily perceive these mechanisms as pervert state presence or coercion.

Yet, the interaction between police officers and piracy retailers is, as observed in the San Juan de Dios market, ambiguous and uncertain. Sellers must pay monthly fees, coutas which constitute a mechanism of coercion; in turn, retailers are allowed to operate and receive critical information. The information and protection provided by madrinas to sellers in the marketplace can however never guarantee immunity. Shifty and unreliable police may act without notice or seize the merchandise of a cuota-paying vendor. In this context, corruption does not engender reliable mechanisms, it entails an extent of uncertainty and risk. This becomes tangible in falsas alarmas, in unexpected police action, or when a madrina directs police action against a rival seller. All in all, the corruption system around the sale of bootleg is not stable.

Hence, do the mechanisms observable in mordidas, cuotas, madrinas and pita$z o s$ in the retail of bootleg at the San Juan de Dios market expand the presence of the state? Yes, but they do not account for (parallel) state power. Rather, these are resources to handle with remote state presence. In order to establish this, the figure of the madrina, the middleman joining state and illegal actors, is essential. Madrinas mediate contact between police officers and bootleg retailers; they collect financial resources and socialise critical police information. Madrinas generate a buffer where illegality can exist by administrating, directing or neutralising police action. Hence, the madrina does not substitute or erode the state, he indeed uses it to regulate networks of supply and retail. 
Corruption engenders a buffer through which madrinas steer remote state presence: the police appears and disappears in the marketplace to seize (or not) bootlegged material, selectively enforcing the rule of law.

Police presence is however required, since the national state is accountable for commercial agreements and international pressure. Corporate lobbies efficiently mobilise to set legal mechanisms in action demanding protection of their commercial interests. Encroached on its realm of power, the national state is urged to take action against infringements on intellectual property rights. As a result, the Mexican state is trapped into two sets of interests. From above, there is the rule of law emerging from global neoliberalism and corporate power. From below, piracy entrepreneurs, sellers and madrinas form another economic class holding a certain extent of power. The "war on piracy" seeks not to reduce the sale of bootlegged merchandise, but to provide evidence on Mexico's commitment to copyright enforcement.

Police action against retail of pirated CDs and DVDs in Mexico does not enforce the rule of law, it gives evidence of remote state presence embedded in elusive networks of loyalties and exchanges of values. This conforms the black spot in the anti-piracy programme of the Mexican federal government.

\section{WRAPPING UP}

The ethnography on the political economy of corruption presented in this article described mordidas, cuotas, madrinas and pitazos. These are mechanisms visible in the retail of pirated CDs and DVDs in Mexican marketplaces. They provide evidence on the ambivalent relation between state and illegal actors. As discussed, police and sellers do not form two separate sets of actors, they are instead entrenched in a net of ambiguous interests. The arrangements and exchanges between them are however unstable. Neither erosion nor expansion, the impact of illegality and corruption on the state is unclear. Police action against sell of piracy takes place in a vague set of loyalties, it constitutes remote state presence. State actors profit from and tolerate illegality, but they are shifty, engendering much unpredictability and risk.

Anti-piracy programmes overlook the net of loyalties among piracy vendors, federal police, and municipal agents. As a result, security polices fail at addressing the multidirectional exchanges of values between these actors. In the long run, the success of policies for the control of illegality will depend on the capacity to tackle the context in which state and illegal actors are embedded. 


\section{REFERENCES}

AGUIAR, José Carlos G., 2010, "Neoliberalismo, piratería y protección de los derechos de autor en México", Renglones, 62: 1-23.

AGUiAr, José Carlos G., and María Eugenia SuÁreZ DE GARAY (eds.), 2008, Policía, Seguridad y Transición Política: Acercamientos al Estado del México Contemporáneo. Amsterdam, Cuadernos del CEDLA.

BAILey, John, and Lucía DAMMERT, 2006, Public Security and Police Reform in the Americas. Pittsburgh, University of Pittsburgh Press.

BARTRA, Roger, and Eugenia HUerTA, 1975, Caciquismo y Poder Político en el México Rural. México, Siglo Veintiuno Editores.

BAYART, Jean-François, 1999, “The 'Social Capital' of the Felonious State”, em Jean-François Bayart, Stephen Ellis, and Beatrice Hibou (eds.), The Criminalization of the State in Africa. Bloomington, Indiana University Press, 32-48.

BAYART, Jean-François, Stephen ELLIS, and Beatrice HIBOU (eds.), 1999, The Criminalization of the State in Africa. Bloomington, Indiana University Press.

BLOK, Anton, 1975, The Mafia of a Sicilian Village, 1850-1960: A Study of Violent Peasant Entrepreneurs. London, William Cowes Sons.

— , 2001, Honour and Violence. Cambridge and Malden, MA, Polity Press.

CANO, Ignacio, and Nilton SANTOS, 2001, Violência Letal, Renda e Desigualdade no Brasil. Rio de Janeiro, 7 Letras.

CHABAL, Patrick, and Jean-Pascal DALOZ, 1999, Africa Works: Disorder as Political Instrument. Bloomington, Indiana University Press.

CROSS, John C., 1998, Informal Politics: Street Vendors and the State in Mexico City. Stanford, Stanford University Press.

CUNNINGHAM, Hilary, and Josiah HEYMAN, 2004, "Introduction: mobilities and enclosures at borders", Identities, 11 (3): 289-302.

DAMMERT, Lucía, 2007, Perspectivas y Dilemas de la Seguridad Ciudadana en América Latina. Quito, FLACSO Ecuador.

DE LA PEÑA, Guillermo, 2000, "Corrupción e informalidad", in Claudio Lomnitz-Adler (ed.), Vicios Publicos, Virtudes Privadas: La Corrupción en México. Mexico, CIESAS and Miguel Ángel Porrúa, 1 18-123.

DE LA PEÑA, Guillermo, and Agustín ESCOBAR LATAPÍ, 1986, Cambio Regional, Mercado de Trabajo y Vida Obrera en Jalisco. Guadalajara, Colegio de Jalisco.

DIAMINT, Rut, 2004, "Security challenges in Latin America", Bulletin of Latin American Research, 23: 43-62.

EVANS, Mark, and Jonathan DAVIES, 1999, "Understanding policy transfer: a multi-level, multi-disciplinary perspective”. Public Administration, 7 (2): 361-385.

GUPTA, Akhil, 2005, "Narratives of corruption: anthropological and fictional accounts of the Indian State", Ethnography, 6: 5-34.

HALLER, Dieter, and Cris SHORE, 2005, Corruption: Anthropological Perspectives. London and Ann Arbor, MI, Pluto.

HASTY, Jennifer, 2005, "The pleasures of corruption: desire and discipline in Ghanaian political culture", Cultural Anthropology, 20 (2): 271 -301.

HEIDENHEIMER, Arnold J. (ed.), 1970, Political Corruption: Readings in Comparative Analysis. New Brunswick, NJ, Transaction Books. 
HeIDENHEIMER, A. J., and M. JOHNSTON, 2005, Political Corruption: Concepts and Contexts. Brunswick, Transaction.

HEYMAN, Josiah McC., 1999, States and Illegal Practices. Oxford and New York, Berg. HIBOU, Béatrice, 1999, “The 'social capital' of the State as an agent of deception”, in Jean-Francois Bayart, Stephen Ellis and Beatrice Hibou (eds.), The Criminalization of the State in Africa. Bloomington, Indiana University Press, 69-1 13.

INEG, 2005, Census 2005, Instituto Nacional de Estadística y Geografía, available at $<$ http://www.inegi.org.mx/est/contenidos/Proyectos/ccpv/default.aspx >.

KNIGHT, Alan, 1986, The Mexican Revolution. Cambridge and New York, Cambridge University Press.

KNIGHT, Alan, and W. G. PANSTERS, 2005, Caciquismo in Twentieth-Century Mexico. London, Institute for the Study of the Americas.

KOONINGS, Kees, and Dirk KRUIJT (eds.), 2004, Armed Actors: Organised Violence and State Failure in Latin America. London and New York, Zed Books.

LOMnitZ-Adler, Claudio (ed.), 2000, Vicios Públicos, Virtudes Privadas: La Corrupción en México. México, CIESAS and Miguel Ángel Porrúa.

MARTíneZ De MurguíA, Beatriz, 1999, La Policía en México: Orden Social o Criminalidad?, Mexico, Planeta.

MORRIS, Stephen, 2000, "La 'política acostumbrada' o 'política insólita'? El problema de la corrupción en el México contemporáneo”, in Claudio Lomnitz-Adler (ed.), Vicios Públicos, Virtudes Privadas: La Corrupción en México. México, CIESAS and Miguel Ángel Porrúa, 221-239.

NUGENT, Paul, and A. I. ASIWAJU (eds.), 1996, African Boundaries: Barriers, Conduits, Opportunities. London, Pinter.

OPPENHEIMER, Andrés, 1996, Bordering on Chaos: Guerrillas, Stockbrokers, Politicians, and Mexico's Road to Prosperity. Boston, Little Brown and Co.

PANSTERS, Will, 1997, Citizens of the Pyramid: Essays on Mexican Political Culture. Amsterdam, Thela Publishers (Thela Latin America series, 7).

PAOLI, Letizia, 2003, Mafia Brotherhoods: Organized Crime, Italian Style. Oxford, Oxford University Press.

RESA, Carlos, 2001, El Estado como Maximizador de Rentas del Crimen Organizado: El Caso del Tráfico de Drogas en México. Mexico, Biblioteca de Ideas del Instituto Universitario de Gobernabilidad.

ROITMAN, Janet, 2006, "The ethics of illegality in the Chad Basin”, in Jean Comaroff and John Comaroff (eds.), Law and Order in the Postcolony. Chicago and London, The University of Chicago Press, 247-272.

ROSE, Richard, 1991, "What is lesson drawing?", Journal of Public Policy, 1 1: 3-30.

SUÁREZ DE GARAY, María Eugenia, 2006, Los Policías: Una Averiguación Antropológica. Guadalajara, Instituto Tecnológico y de Estudios Superiores de Occidente (ITESO), Universidad de Guadalajara.

TUlChin, Joseph, and M. RUTHENBURG, 2006, Toward a Society under Law: Citizens and Their Police in Latin America. Washington and Baltimore, Woodrow Wilson Center Press and Johns Hopkins University Press.

VAN REENEN, Piet, 2004, "Policing extensions in Latin America", in Kees Koonings and Dirk Kruijt (eds.), Armed Actors: Organised Violence and State Failure in Latin America. London and New York, Zed Books, 33-51. 
VAN SCHENDEL, Willem, 2005, The Bengal Borderland: Beyond State and Nation in South Asia. London, Anthem Press.

WEBER, Max, 1978, Economy and Society: An Outline of Interpretive Sociology. Berkeley, University of California Press, edited by Guenther Roth and Claus Wittich.

A relação ambígua entre o Estado e os atores ilegais: o mercado da pirataria no México - José Carlos G. Aguiar - Department of Latin American Studies (TLCA), University of Leiden, Países Baixos • j.c.g.aguiar@hum.leidenuniv.nl

Quando surgiram os governos democráticos na América Latina, a perspetiva neoliberal da lei e da ordem constituiu-se como o modelo de segurança dominante na região. Esta abordagem baseia-se na oposição entre o Estado e os agentes da ilegalidade, como se fossem dois conjuntos de atores distintos. Influenciado por este modelo, o presidente mexicano Vicente Fox lançou um programa alargado contra a pirataria, pretendendo erradicar a venda da contrafação. A partir de material etnográfico recolhido no mercado de San Juan de Dios, em Guadalajara, examino as interações entre vendedores de mercadoria pirata e agentes da polícia. Argumento que os programas para a aplicação da lei não afetaram a economia política da corrupção e que ignoram a rede de lealdades ambíguas que envolvem o Estado e os atores ilegais. A antropologia do Estado oferece os princípios para uma crítica sobre as políticas de segurança neoliberais.

PALAVRAS-CHAVE: pirataria, ilegalidade, polícia, México. 